Research Article

\title{
Understanding the Effects of Changing Weather: A Case of Flash Flood in Morogoro on January 11, 2018
}

\author{
Offoro Neema Kimambo $\mathbb{D D}^{1,2}$ Hector Chikoore, ${ }^{3}$ and Jabulani Ray Gumbo $\mathbb{1 D}^{4}$ \\ ${ }^{1}$ Department of Geography and Environmental Studies, Solomon Mahlangu College of Science and Education, \\ Sokoine University of Agriculture, Morogoro, Tanzania \\ ${ }^{2}$ Department of Ecology and Resource Management, School of Environmental Sciences, University of Venda, \\ Thohoyandou, South Africa \\ ${ }^{3}$ Department of Geography and Geo-Information Sciences, School of Environmental Sciences, University of Venda, \\ Thohoyandou, South Africa \\ ${ }^{4}$ Department of Hydrology and Water Resources, School of Environmental Sciences, University of Venda, \\ Thohoyandou, South Africa
}

Correspondence should be addressed to Offoro Neema Kimambo; offoro@gmail.com

Received 8 November 2018; Revised 14 March 2019; Accepted 26 March 2019; Published 21 April 2019

Guest Editor: Sushil K. Dash

Copyright (C) 2019 Offoro Neema Kimambo et al. This is an open access article distributed under the Creative Commons Attribution License, which permits unrestricted use, distribution, and reproduction in any medium, provided the original work is properly cited.

\begin{abstract}
Floods are the leading cause of hydrometeorological disasters in East Africa. Regardless of where, when, and how the event has happened, floods affect social security as well as environmental damages. Understanding floods dynamics, their impacts, and management is thus critical, especially in climate risk assessment. In the present study, a flash flood (a case of an episodic hydrological event) which happened on January 11, 2018, in Morogoro, Tanzania, is examined and synthesized. Data were courtesy of the National Oceanic and Atmospheric Administration Global Forecasting System (NOAA GFS) (forecast data), Tanzania Meteorological Agency (TMA), and Sokoine University of Agriculture (for the automatic weather data). With the help of ZyGRIB-grib file visualization software (version 8.01, under General Public License (GNU GPL v3)), the forecast data and patterns of the observation from the automatic weather station (temperatures, wind speed and directions, rainfall, humidity, and pressure) and the long-term rainfall data analysis in the study area made it possible. This study contributes to the knowledge of understanding the changing weather for planning and management purposes. Both forecasts and the observations captured the flash flood event. The rain was in the category of heavy rainfall (more than $50 \mathrm{~mm}$ per day) as per the regional guidelines. The synergy between the forecasts and the 30-minute weather observation interval captured the fundamental weather patterns that describe the event. For studying the nature and impacts of flash floods in the region, the integration of automatic weather observation into the systems of national meteorological centers is inevitable. Additionally, as part of an integrated disaster risk reduction effort, there is a need for a review on catchment management strategies.
\end{abstract}

\section{Introduction}

Flash floods according to the World Meteorological Agency (WMO) are defined as floods of "short duration with a relatively high peak discharge" [1]. Flash floods are studied as climatological phenomena [2] or as hydrological phenomena [3]. Several factors are responsible for flash floods occurrence including meteorological (e.g., intensity, duration, amount, and time-space variation in rainfall) and watershed characteristics such as area, length, slope, type of soil, vegetation cover, and land use $[4,5]$. However, there are also many other factors which are unknown [6]. Flash floods may be accompanied by other events such as mudslides, but very rare [7]. Flash floods are also ranked high among natural disasters [8]. Recent studies indicate that there is an increasing trend of floods over about half of the globe but with greater regional and local variability [9]. 
In East Africa, for example, flash floods are the leading hydrometeorological disaster [10]. Due to the predicted changes in climate in the region [11], for example, increased precipitation and flooding, major cities and towns are at higher risks. A recent study [12] specifically in Tanzania suggests that floods are driven by heavy rainfall patterns and are widely distributed and overtime have caused significant economic damages and causalities. On the other hand, documentation and track records of this phenomenon [13] is limited. The ability to predict flash floods is also limited and difficult due to the complex interaction between meteorological and hydrological variables. However, the prediction of flash floods has been investigated and verified using hydrological models [4]. Recent advances have demonstrated, for example, weather radar has the capability to predict these events ahead of time [5], but they can also be assisted by other means of investigations and therefore they can synergistically provide early warning to the vulnerable communities.

Recent cases (information available online at http:// floodlist.com/tag/tanzania and https://reliefweb.int/country/ tza) of floods in Tanzania indicate an increasing intensity, and the trend is more than ever before [14]. A recent study [15] conducted in Tanzania and Nigeria on coping strategies to climate impacts suggests differences in coping strategies across regions. Tanzania climate is very variable, and it is mostly regulated by the Intertropical Convergence Zone (ITCZ) which defines rain pattern in the country. Also, El Niño and La Niña which influence drought and floods, respectively, define rain pattern in the region as well [16]. Monsoon, thunderstorms, and local climate (e.g., orographic effects) also play an important role in the climate of Tanzania. Other causes have been studied and narrated (e.g., Kijazi and Reason [17] on the 2006 flood event in the northern part of Tanzania) strong warming over the Indian Ocean coupled with the convective zone over the western Indian Ocean, warming of the Somali Coast, and an easterly moisture flux are linked with floods in Tanzania [17].

Increase in population and urbanization as well as poor land management are among other factors that increase vulnerability to floods $[16,18]$. Land use changes (e.g., pollution, erosion, and silting of the river beds) have been reported as the major contributor in reducing the Ngerengere River carrying capacity [19]. Surveys and anecdotal evidence in the Ngerengere River catchment also suggest that conversion of natural areas into agricultural field leads to increased surface runoff and the magnitude of floods specifically the upper part of the catchment [20].

According to WMO, disaster risk knowledge, forecasting, dissemination, and preparedness are key elements of early warning systems [5]. Previous studies indicate that, in Tanzania, floods are recurrent phenomena and have been ranked high on the list of hazards $[16,21]$. Apart from the direct effects, indireclty heavy rainfall is also secondary key to waterborne diseases [22] and other related problems in water bodies, for example, proliferation of algal blooms [3]. It is high time now to invest in understanding the occurrence and complexities that are involved in predicting as well as setting the best resilience options (i.e., physical, ecological, and sociological).

On January 11, 2018, high rainfall event was observed in Morogoro Region in Tanzania which caused damages to properties and critical infrastructure, such as water and electricity supply lines, as well as the death of one person. Normally, the dominant weather phenomenon for the month of January is associated with the Intertropical Convergence Zone (ITCZ) as it moves south and retreats to the north from the south [17]. During the event, the tropical cyclone (TC) Berguitta was the dominant weather system in the Indian Ocean. The current study aimed to examine and synthesize the flash flood event on January 11, 2018, which occurred in Morogoro, specifically, data utilization for understanding the effects of changing weather over a catchment.

\section{Materials and Methods}

2.1. Study Area Description. The Ngerengere catchment is the subcatchment (Figure 1) of the main Wami Ruvu basin and located in Morogoro Region, Tanzania, within longitudes and latitudes of $37^{\circ} 32^{\prime} \mathrm{E} 6^{\circ} 51^{\prime} \mathrm{S}, 38^{\circ} 09^{\prime} \mathrm{E} 6^{\circ} 69^{\prime} \mathrm{S}, 37^{\circ} 38^{\prime} \mathrm{E}$ $7^{\circ} 09^{\prime} \mathrm{S}$, and $38^{\circ} 38^{\prime} \mathrm{E} 7^{\circ} 05^{\prime} \mathrm{S}$, respectively. It covers approximately an area of $2780 \mathrm{~km}^{2}$ and is characterized by a tropical climate [23]. The population in the catchment is estimated to be about 1 million [24]. Climate and land use are believed to have caused significant impacts on the catchment [23]. A recent survey in Wami/Ruvu basin indicates temperatures are varying (very hot days and reducing cold days), rising evapotranspiration (normally higher than rainfall) and moisture deficits, increasing uncertainty in rainfall characteristics, increasing frequency of extreme events, floods, and a long period of no rainfall [25]. Daily temperatures range from 22 to $33^{\circ} \mathrm{C}$ and less agreement in rainfall $[25,26]$. The uncertainities in rainfall is mainly due to the complex interaction of solar radiations, atmosphere, soil and water heat storage, topography and land cover, and vegetation type [25]. A recent study [27], for example, found significant changes $\left(9 \mathrm{~km}^{2}\right.$ to $\left.82 \mathrm{~km}^{2}\right)$ in impervious surfaces around Morogoro town which might be the reasons for the formation of urban heat island. This study demonstrated urban heat index which was linked to variability in climate.

The catchment is characterized by bimodal rainfall pattern, the long rains or Masika (March, April, and May) and the short rains or Vuli (September, October, and November). Most part of the catchment receives annual rainfall varying from 800 to $1500 \mathrm{~mm}$, whereby the highest is received in the Uluguru Mountains [23]. In the upper Ngerengere River, there are tributaries (Mzinga, Mlali, Lukurunge, and Mgeta Rivers) which are flowing into the Mindu Dam and the discharge from the Dam is spilled into the Ngerengere River which adjoins with Morogoro, Bigwa, Mlali, and Ruvu tributaries to the main Ruvu River.

2.2. Methods. We analyzed twenty-four (24) hours of observations (at an interval of 30 minutes) for temperature $\left({ }^{\circ} \mathrm{C}\right)$, dewpoint temperatures $\left({ }^{\circ} \mathrm{C}\right)$, wind speed (knots) and 


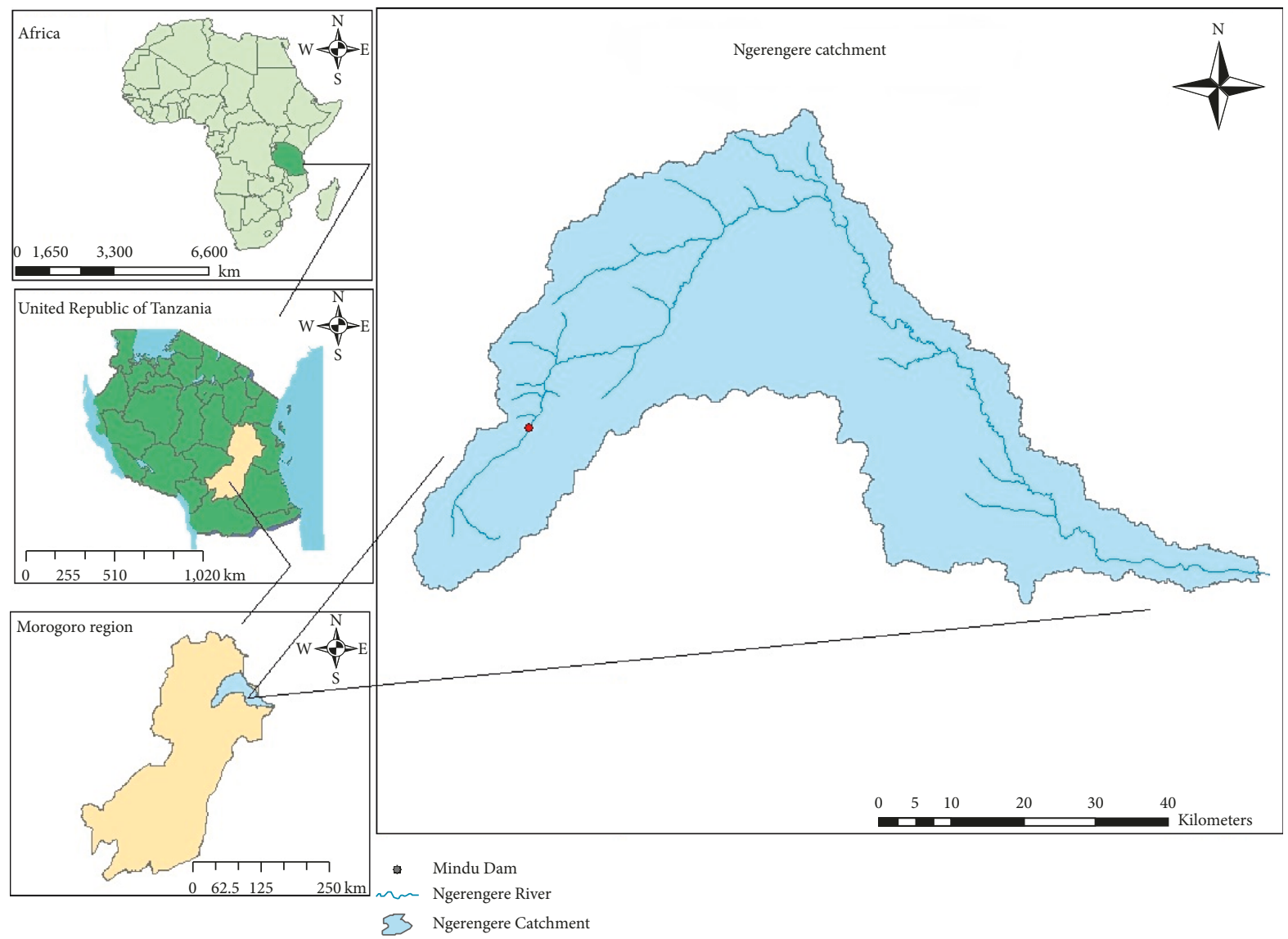

FIGURE 1: Map of Ngerengere catchment in Morogoro Region.

direction (degree), pressure $(\mathrm{mmHg})$, rainfall $(\mathrm{mm})$, and relative humidity (\%) all downloaded from an automatic weather station situated at Mazimbu, Sokoine University of Agriculture, in Morogoro. We used ZyGrib (grib files visualization software, version 8.01, General Public License (GNU GPL v3 available online at http://www.zygrib.org/) to visualize a forecast of a day before (January 10, 2018) from National Oceanic and Atmospheric Administration (NOAA) Global Forecasting Services (GFS). The aim was to examine the prevailing large-scale weather pattern for January 10 and 11, 2018. ZyGrib domain settings were as follows: Weather Centre 7, Model 81, run time Wednesday 2018-01-10 06:00 UTC to Saturday 2018-01-20 06:00 UTC; area $21^{\circ} \mathrm{S}, 007^{\circ} \mathrm{E}$ and $007^{\circ} \mathrm{N}, 061^{\circ} \mathrm{E}$; and the resolution of $0.25^{\circ} * 0.25^{\circ}$. The following parameters from the models were studied: mean sea level pressure (MSLP) (mbar), geopotential height (m) (at $850 \mathrm{hPa}$ and $500 \mathrm{hPa}$ ), air temperature $\left({ }^{\circ} \mathrm{C}\right.$ ) (at $2 \mathrm{~m}, 850 \mathrm{hPa}$, and $500 \mathrm{hPa}$ ), and dewpoint temperature $\left({ }^{\circ} \mathrm{C}\right)($ at $2 \mathrm{~m})$. In addition to that, wind (at $10 \mathrm{~m}, 850 \mathrm{hPa}$, and $500 \mathrm{hPa}$ ), total precipitation $(\mathrm{mm})$, clouds cover, surface convective inhibition (CIN) $(\mathrm{J} / \mathrm{kg})$, surface convective available potential energy (CAPE) $(\mathrm{J} / \mathrm{kg}$ ), and wind gust (surface) were also investigated.

2.3. Study Design and Data Analysis. This is a case study design with the intent to examine, synthesize, and describe the nature of the flash flood which happened on January 11,
2018, in Morogoro municipality and how it can be used to study catchment management. Most of the figures in the study were produced using the ZyGrib-grib file visualization software, version 8.01, under General Public License (GNU GPL v3, available at http://www.zygrib.org), and XLSTAT (Addinsoft (2019), XLSTAT statistical and data analysis solution, Boston, USA; https://www.xlstat.com) for the patterns, and statistical inferences to all the investigated parameters and cross-case synthesis were examined and used for drawing our conclusions.

\section{Results and Discussion}

Under this section, all the findings are presented and discussed.

3.1. Model Forecasts. Most of the flash floods result from deep convective clouds [28]. A forecast form NOAA GFS model run on Wednesday 2018-01-11 06:00 UTC indicated that the entire country (Tanzania) was cloudy (Figure 2(a)), and a Col (i.e., area of slack pressure between two anticyclones and two depressions) (Figure 2(b)) was situated at the central to northeastern part of the country. During the date of event (heavy rainfall), large-scale weather systems, namely, ITCZ and tropical storm (Berguitta), triggered the rainfall activity in the area of interest (Morogoro). 


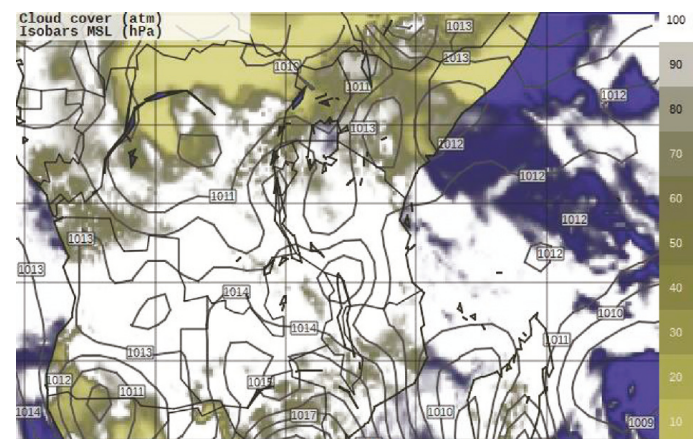

(a)

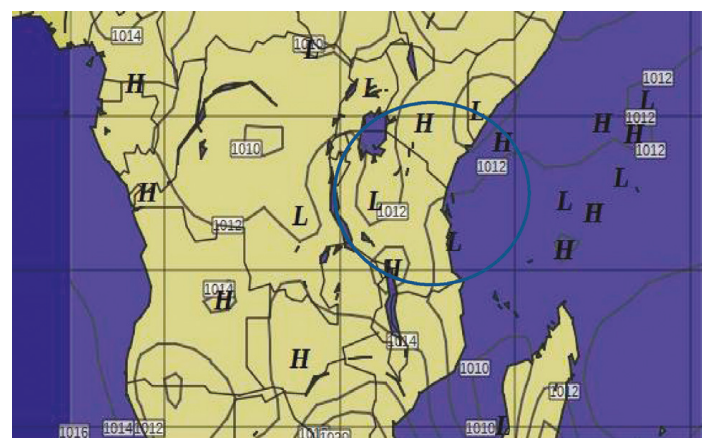

(b)

FIgURE 2: Cloud cover overlaid with the mean sea level pressure (a) and surface high- and low-pressure centers (b) at 0900 UTC. The lowpressure centers are an indication of areas of surface convergence. All maps were from NOAA-GFS, Wednesday 2018-01-10 06:00 UTC, generated using zyGRID-Grib files visualization software (available at http://www.zygrib.org/).

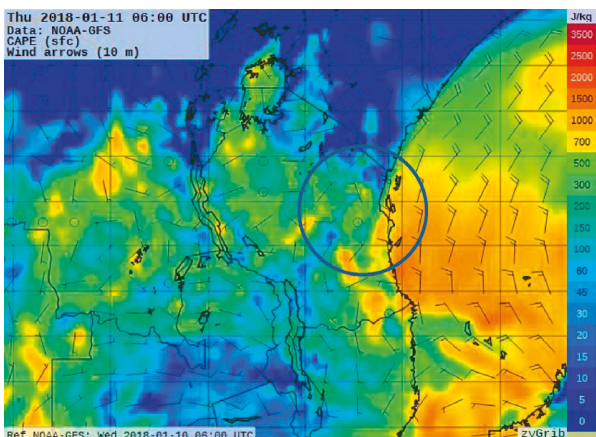

(a)

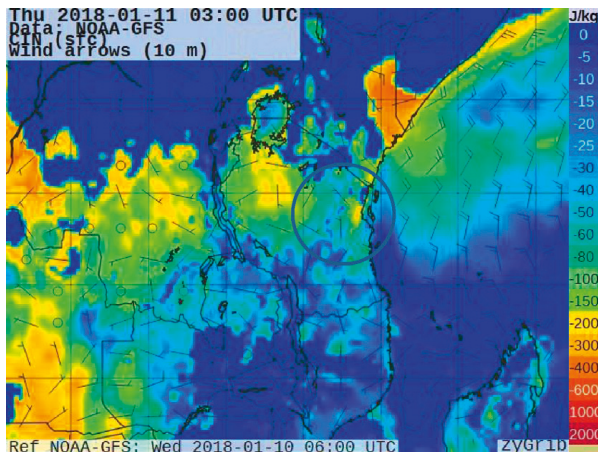

(c)

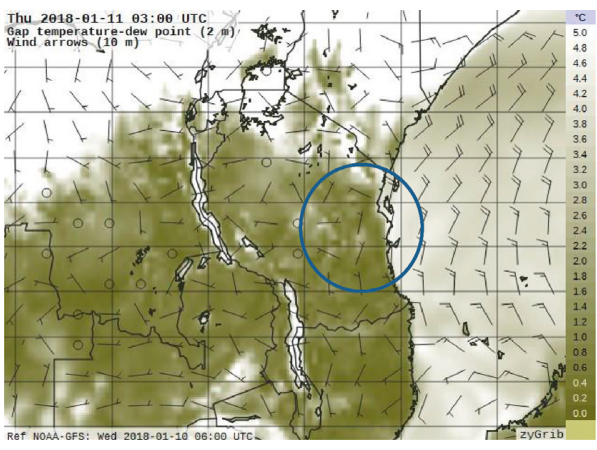

(b)

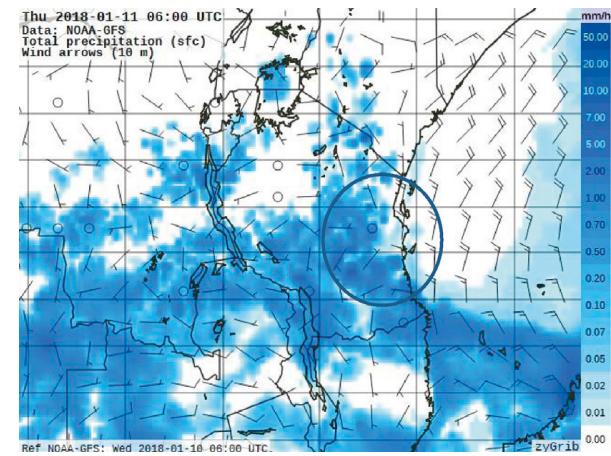

(d)

Figure 3: Convective available potential energy $(\mathrm{J} / \mathrm{kg})$ at $09: 00 \mathrm{am}(\mathrm{a})$; a gap between air temperature $\left({ }^{\circ} \mathrm{C}\right)$ and dewpoint temperature $\left({ }^{\circ} \mathrm{C}\right)$ (b); convective inhibition $(\mathrm{J} / \mathrm{kg})(\mathrm{c})$; total surface precipitation $(\mathrm{mm})(\mathrm{d})$ all overlaid with wind at $10 \mathrm{~m}$ (forecast data from NOAA-GFS on Wednesday 2018-01-10 0600 UTC and generated by using zyGRID-grib files visualization software, available at http://www.zygrib.org/). The circled area is the area of interest of explicitly low pressure and converging surface wind.

For assessing the large-scale disturbances leading to severe weather, convective available potential energy (CAPE) is normally used $[29,30]$. A cross-examination indicated that CAPE values increased from $450 \mathrm{~J} / \mathrm{Kg}$ at around $03: 00 \mathrm{UTC}$ to $1839 \mathrm{~J} / \mathrm{Kg}$ at around 15:00 UTC (Figure 3(a)). On the other hand, convective inhibition (CIN) (energy required to initiate convection) values were ranging from -51 to $-11 \mathrm{~J} / \mathrm{kg}$ (Figure $3(\mathrm{c})$ ) in the specified period. Relative humidity (\%) values were also high (reaching 92\%) (for the estimation of CAPE and CIN with ZyGrib, values can be extracted from the map while navigating the cursor over the area of interest). The air and dewpoint temperature gradient (Figure 3(b)) varied from 0.2 to $0.4^{\circ} \mathrm{C}$ between 0300 and 0600 UTC, which is an indication of high moisture content as well. This among other factors mentioned in the previous sections were responsible for the precipitation (Figure 3(d)).

From the forecast, there was warming over the Indian Ocean and wind flows at both 850 and $500 \mathrm{hPa}$ indicated a moisture flux from the western Indian Ocean (Figures 4(a) and 4(b)).

The vertical velocity (Pascal/seconds) (Figures 5(a) and 5(b)) for both $850 \mathrm{hPa}$ and $500 \mathrm{hPa}$ indicates a significant 


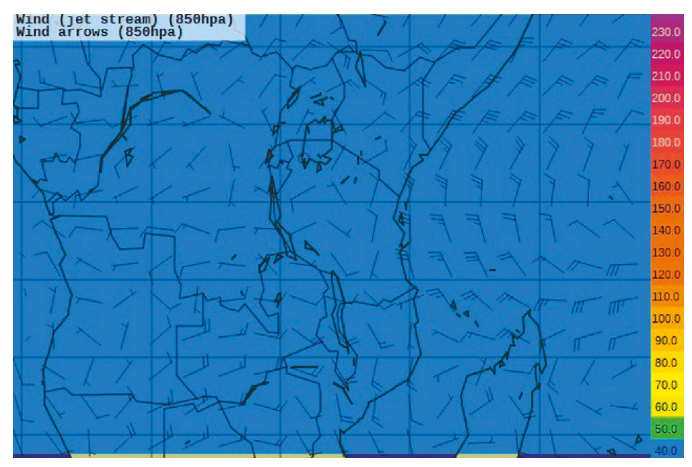

(a)

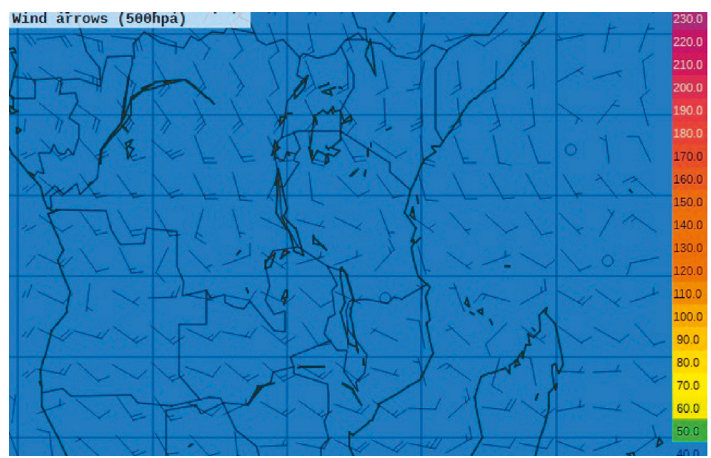

(b)

Figure 4: (a) Wind at $850 \mathrm{hPa}$ and (b) wind at $500 \mathrm{hPa}$ all from NOAA-GFS on Wednesday 2018-01-10 06:00 UTC (all the graphs generated using zyGRID-grib files visualization software, available at http://www.zygrib.org/).

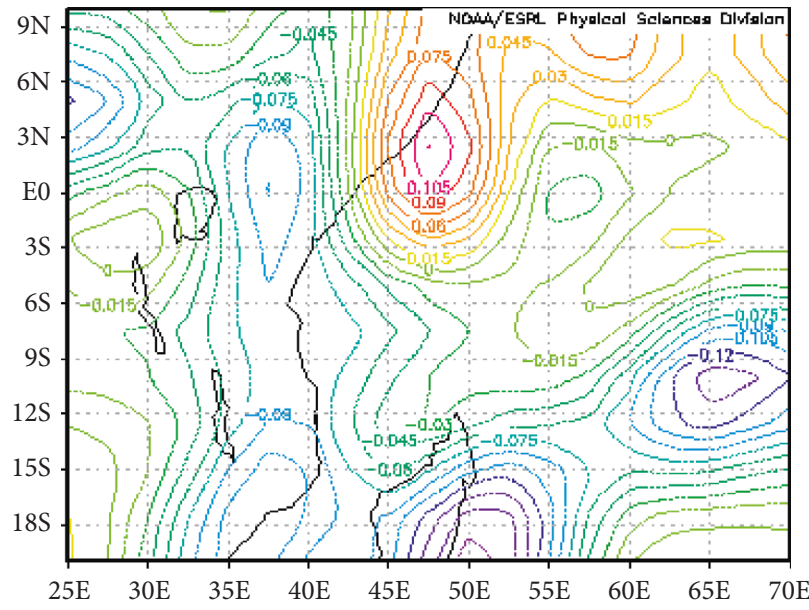

(a)

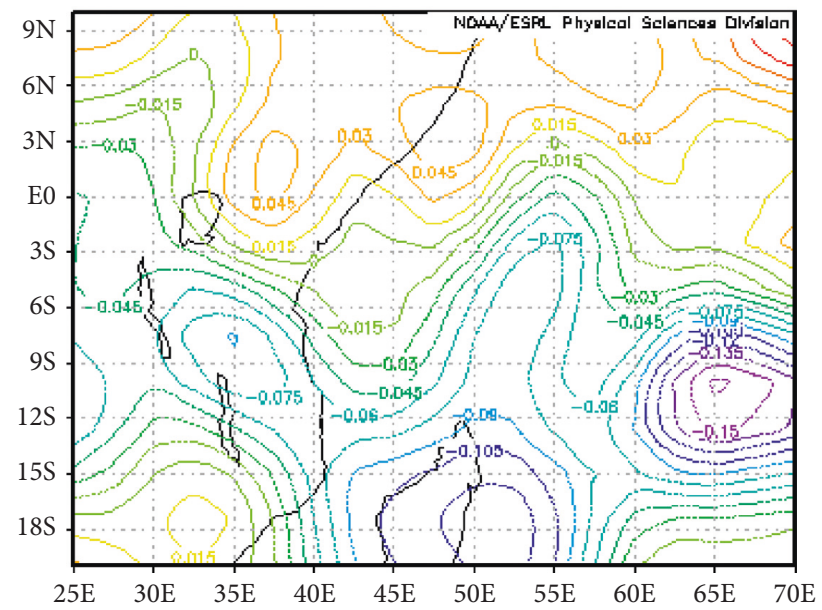

(b)

Figure 5: Vertical velocity (Omega) (Pascal/second) for both $850 \mathrm{hPa}$ (a) and $500 \mathrm{hPa}$ (b) (images provided by the NOAA-ESRL Physical Sciences Division, Boulder Colorado from their website at https://www.esrl.noaa.gov/psd/).

area of vertical velocity which is bulging from the southeastern tip of Tanzania connected to the one which was occurring in the Indian Ocean, East of Madagascar. The dominant weather system during the course of the event over the area was ITCZ (regions of low-pressure systems can also be depicted from Figure 2(b)) which is the normal and regular position during the month of January [17], and over the Indian Ocean, there was a tropical cyclone (TC) Berguitta (Figure 5(b), far eastern Madagascar). The two weather systems together are the ones which influenced the convergence over the area leading to the heavy weatherly activities over the area of interest (study area).

3.2. Surface Observations. As per the automatic weather station data, the event started at around 05:00-09:00 am (0300-0600 UTC) Tanzania local time. Wind speed (Figure 6(a)) was ranging from 5 to $10 \mathrm{knots,} \mathrm{gusting}$ 30 knots towards 09:00 am, and at the same time, wind direction registered a huge variation. On average, the whole day, more than $50 \%$ of wind direction (Figure 6(a)) distribution varied from southwesterly to northwesterly. The air temperature and dewpoint gradient were also so close during the three hours of the event (Figure 6(b)) indicating that there was moisture in the area which was one among the ingredient for the precipitation. This can be confirmed by the moisture amount in the atmosphere which was almost $92 \%$.

At the time of the event, there was also an increase in pressure (Figure 7) which is common (follows normal diurnal variation). From the surface observation (automatic weather station data), it can be deduced that rainfall (Figure 7) intensity ( $92.2 \mathrm{~mm}$ in almost three hours) was very high. Based on this fact, one can hypothesize and test on the variation of the rainfall intensity in the region. The same can also be depicted from the analysis of water level (Figure 8) for Mindu Dam, a domestic water reservoir in the Ngerengere catchment which increased significantly. Preliminaries on the forecasts (i.e., the previous twenty-fourhour rainfall) according to the Tanzania Meteorological Agency (TMA) indicated that Morogoro synoptic station had received the highest rainfall $(85.3 \mathrm{~mm})$ in the country (Figure 9(a)). The satellite image as well could tell the activeness of the weather of the day (Figure 9(b)). 


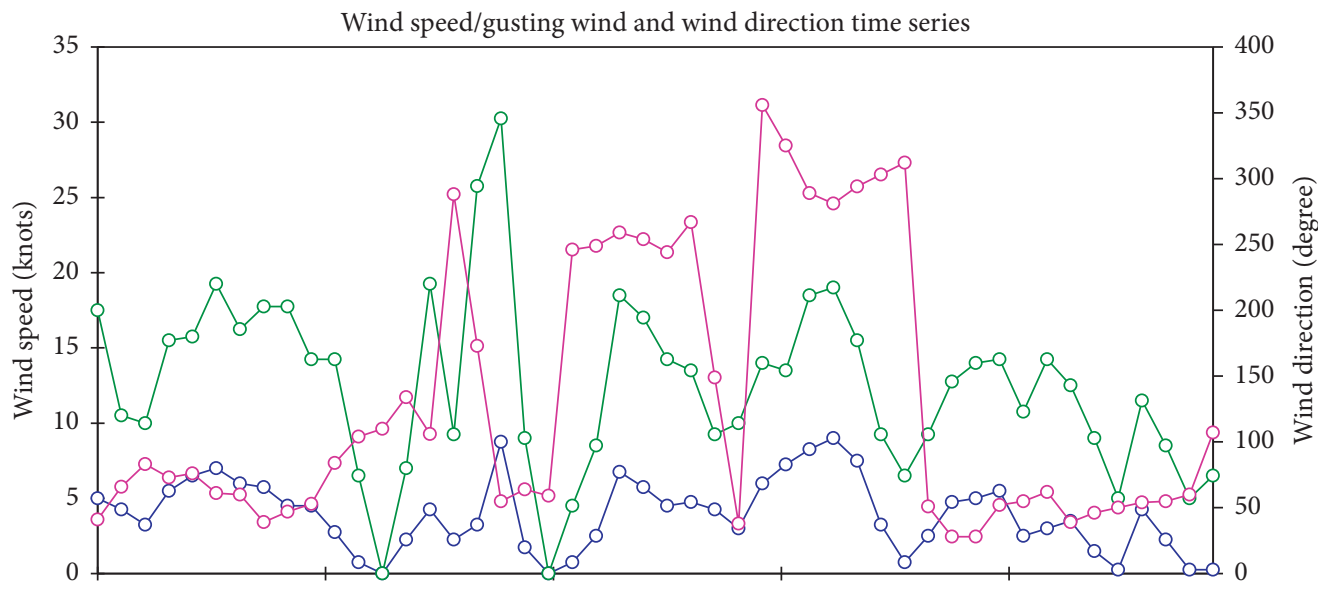

2018/11/01 00:00 2018/11/01 04:48 2018/11/01 09:36 2018/11/01 14:24 2018/11/01 19:12

Time of the day

$$
\begin{aligned}
& \multimap-\text { Wind speed (knots) } \\
& -\circ \text { Gusting wind (knots) } \\
& \multimap-\text { Wind direction (degree) }
\end{aligned}
$$

(a)

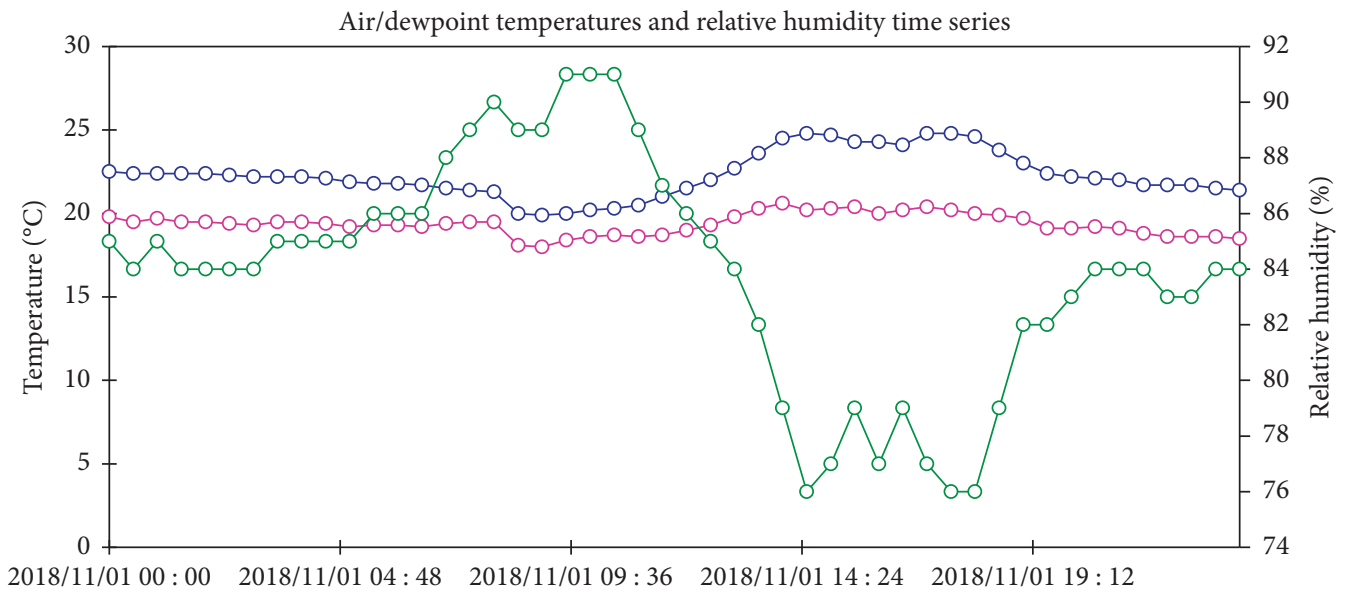

Time of the day

$$
\begin{aligned}
& -\mathrm{O} \text { Air temperature }\left({ }^{\circ} \mathrm{C}\right) \\
& -0 \text { - Dewpoint temperatures }\left({ }^{\circ} \mathrm{C}\right) \\
& -0-\text { Relative humidity }(\%)
\end{aligned}
$$

(b)

Figure 6: Twenty-four-hour wind speed, gusting wind (both in knots), and wind direction (degree) (a) and relative humidity (\%), air temperature $\left({ }^{\circ} \mathrm{C}\right)$, and dewpoint temperature $\left({ }^{\circ} \mathrm{C}\right)(\mathrm{b})$ for the day of January 11, 2018.

General characteristics of the variation of weather parameters (temperature, for example) in the regions show significant variations [31]. Rainfall is more tied to sea surface temperatures (SSTs) [32]. A historical record in the study area also indicates that it is a drought-prone area [33]. To supplement that, a recent study [19] in the Ngerengere catchment which investigated the effects of climate change and land use on the discharge regime demonstrated that climate change and land use have got different effects. This study used soil and water assessment tool (SWAT) and statistical analysis to curb the problem of data. The study also pointed out that there is a huge variation in weather (sometimes, total drying out downstream the catchment and floods). According to Natkhin et al. [19] with regard to the drying out, dry periods (less than $15 \mathrm{~mm}$ of rainfall per week) registered an increasing trend [19]. This was also reported by Kimambo et al. [34] on the standardized precipitation and evapotranspiration index (SPEI) with alteration of positive (positive 2 for wet conditions) and negative (negative 2 for severe drought condition). A comparison for the extreme (per year and for the month of January) rainfall for the period (1971-2012) is demonstrated in Figure 10. It was found that the month of January had also contributed to the cases of extreme rainfall/year in the catchment. However, 


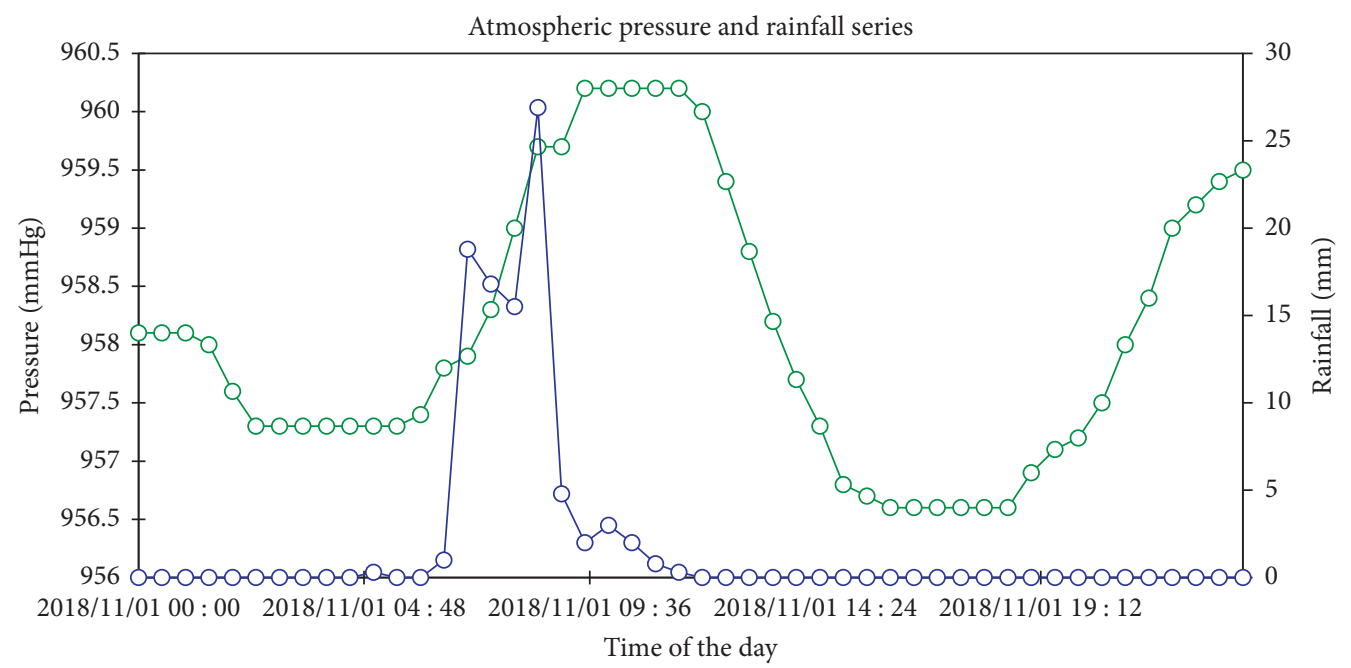

-O- Atmospheric pressure ( $\mathrm{mmHg})$
-O- Rainfall (mm)

Figure 7: Atmospheric pressure $(\mathrm{mmHg})$ and rainfall $(\mathrm{mm})$ series on the $11^{\text {th }}$ of January 2018, Morogoro.

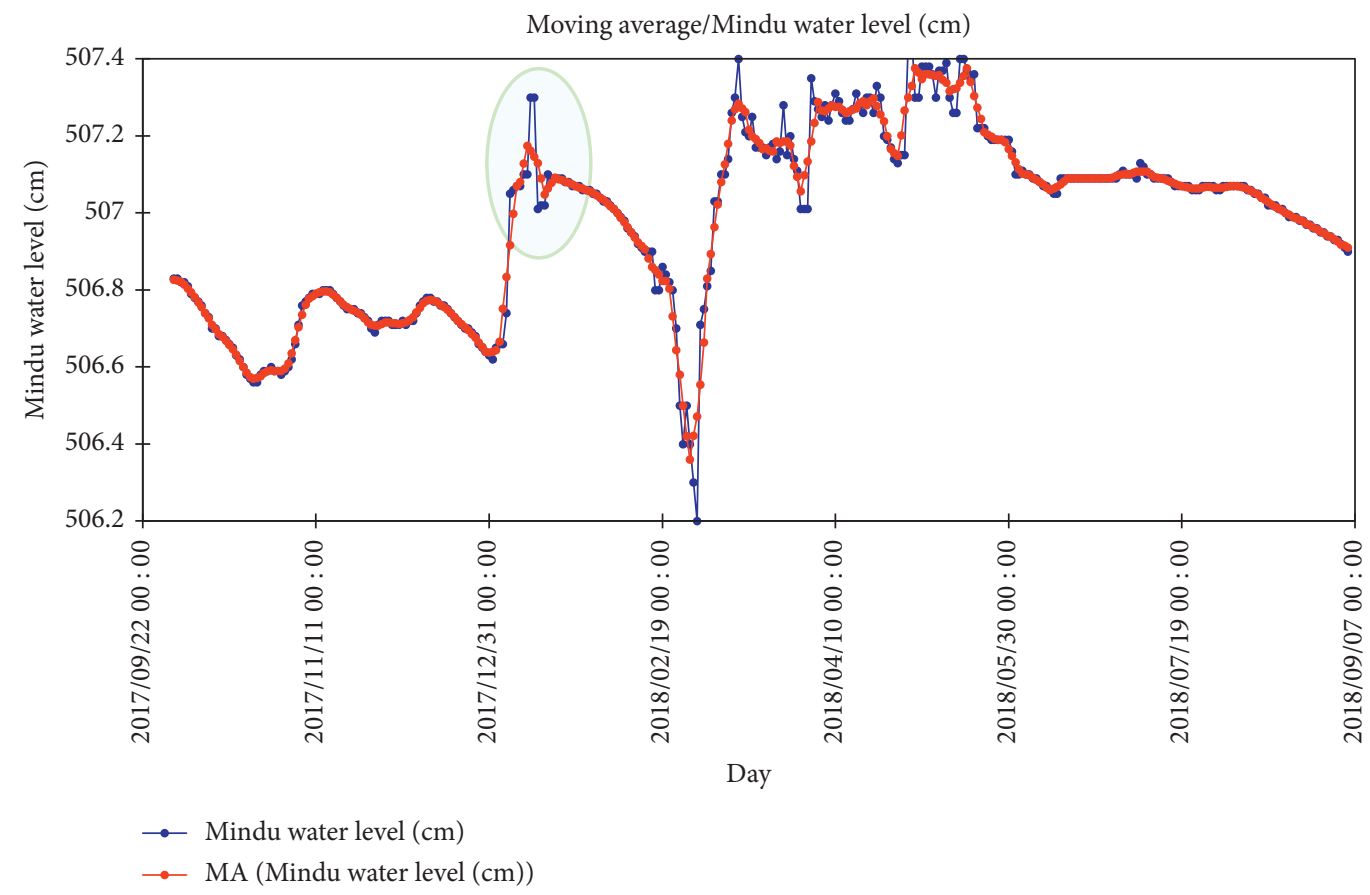

Figure 8: Moving average/water level $(\mathrm{cm})$ for Mindu Dam for a period of October 2017 to August 2018 (data from Wami Ruvu basin office). A sharp increase (cycled) is attributed to the heavy rainfall (a case study being discussed) and thereafter dropping toward the end of the month of February and then an increase in the following months of March, April, and May (MAM), i.e., the rainfall seasons.

that there was a significant difference between the two data distribution meaning that most of the extreme (heavy) cases of rainfall are attributed to other months of the year. Performing Mann-Kendall trend, it was found that there is no significant trend in the two series.

3.3. Associated Impacts and Management. Weather-related extreme events such as flash floods are associated with the economic crisis, societal disturbances, and environmental impacts (e.g., nutrients transports, pollution, and species composition change in the affected area) $[9,35]$. The perception prevailing is that floods are from the prolonged rainfall [14] which may not be always. Short-time rainfall like the case being studied demonstrated even a less-than-a-day rainfall event can also create havoc. The anecdotal observations (Figures 11(a) and 11(b)) showed that the event was so stressful to the locals and damaged properties and some business was inundated (https:// www.youtube.com/watch?v=W1Gj-R1-mto) in the town of Morogoro. Apart from the direct impacts discussed above, the 


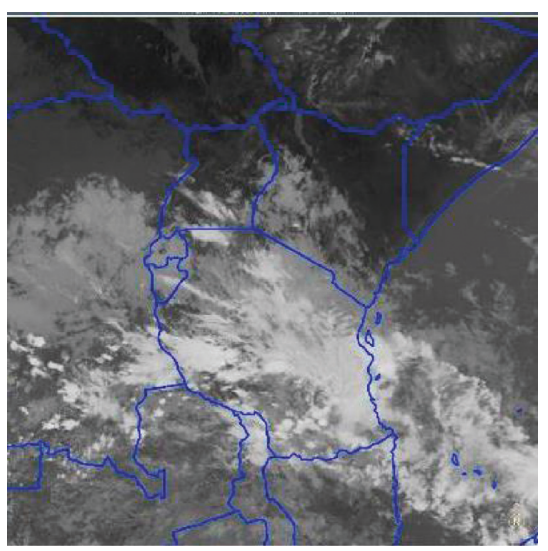

(a)

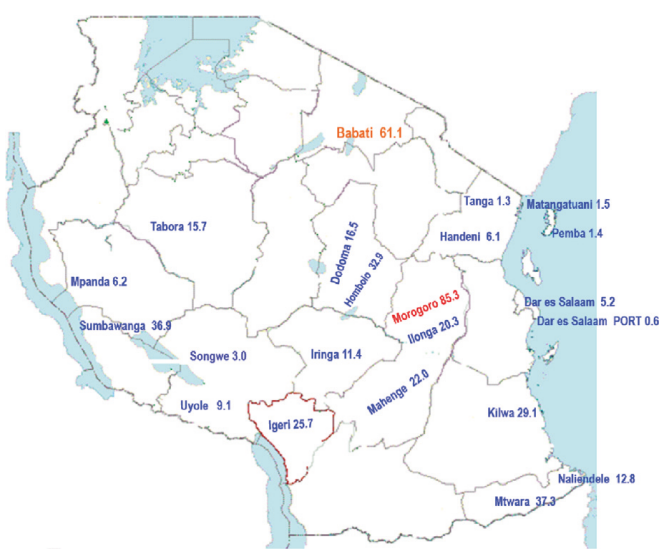

(b)

FIGURE 9: (a) Infrared satellite (IR) image for the day (1015 UTC, 11/01/2018) (retrieved from https://en.sat24.com/en/af/infraPolair) and (b) the twenty-four-hour (January 11, 2018) rainfall $(\mathrm{mm})$ distribution (preliminaries prior to the forecast of the day) in Tanzania as extracted from the official YouTube (https://www.youtube.com/watch?v=ohd4t4BMsnk) channel of the Tanzania Meteorological Agency.

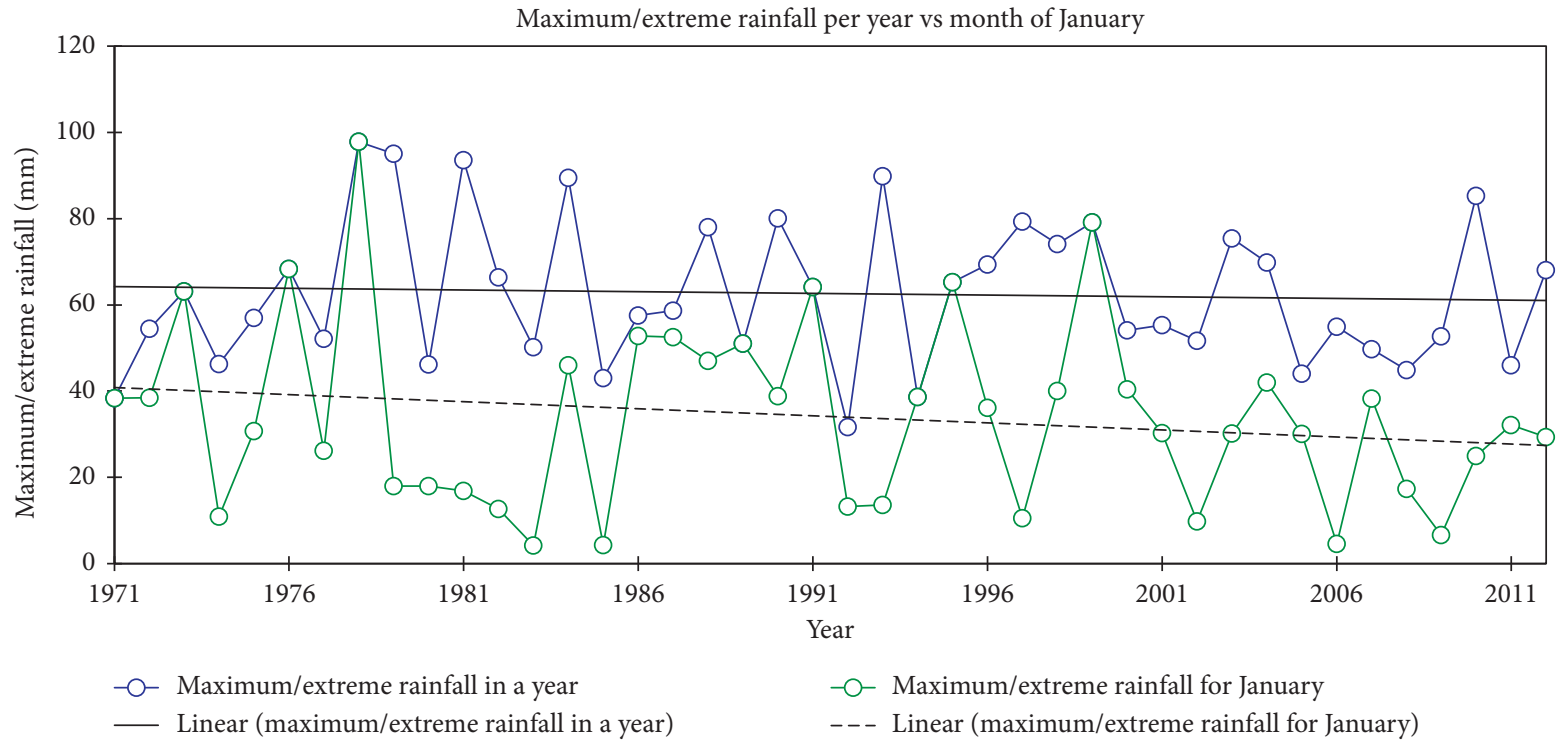

Figure 10: Trend (the Mann-Kendall trend test showed a nonsignificant trend at a 95\% confidence interval, $p$-value $>0.05$ ) for maximum (extreme) rainfall (per year and for the month of January) for Morogoro synoptic (daily rainfall data for the period of 1971-2012, in courtesy of the Tanzania Meteorological Agency, were extracted using an interactive Statistical Package, Instat+ for Windows, version 3.37).

effect of rainfall (for example, heavy rainfall cases) on aquatic systems has been discussed critically [3]. Anderson [36] suggests that a case study approach may be more informative to study river ecological health, for example, studying harmful algal blooms (noxious to the environment) dynamics in a catchment. Heisler et al. [37] also highlight the relationship between nutrients transfer in rivers as a result heavy rainfall (for example, an observation made by the author just a month after a rainy season in Figure 11(c)) algal blooms tend to proliferate. Algal blooms are also common in the study area and they have been associated with variations of both climate and hydrological changes [34].

Normally in risk assessment, three elements are involved, i.e., vulnerability, exposure, and threats. The national adaptation plan [14] does not address specifically what should be done on these short-term impacts. A study by Ringo [38] argues that governance and institutional structures are insufficient in providing structural measures before, during, and after flash floods. Ringo (2018) outlined core areas which can be improved such as lack of disaster experts, delays in relief, and the participatory approach in dealing with the problem. Other case studies [39] in Dar es Salaam, for example, proposed strategies that can be used for risk reduction from the same phenomenon. Wilby and Keenan [40] triangulated the best way to address the issue. This study considered information (e.g., early warning systems, education programs, and mapping the vulnerable areas), institutions (e.g., building codes, public participation, and transparencies), and preparedness (e.g., standing orders and role plays) nexus as the best approach. 


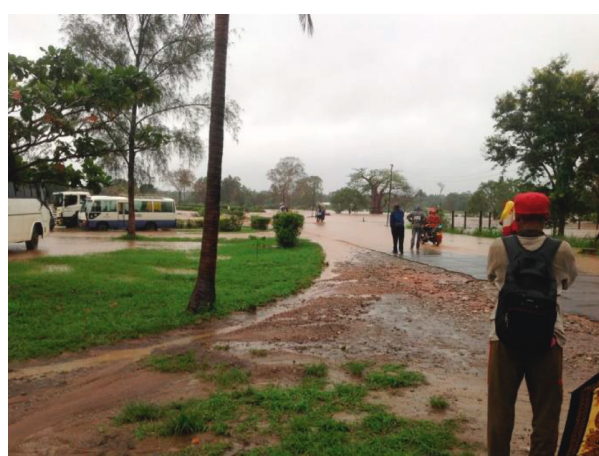

(a)

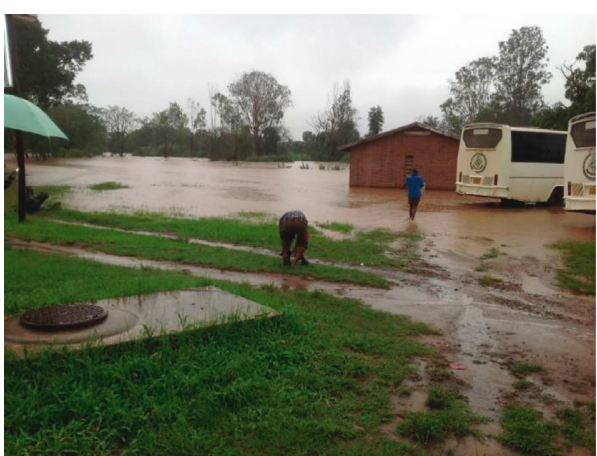

(b)

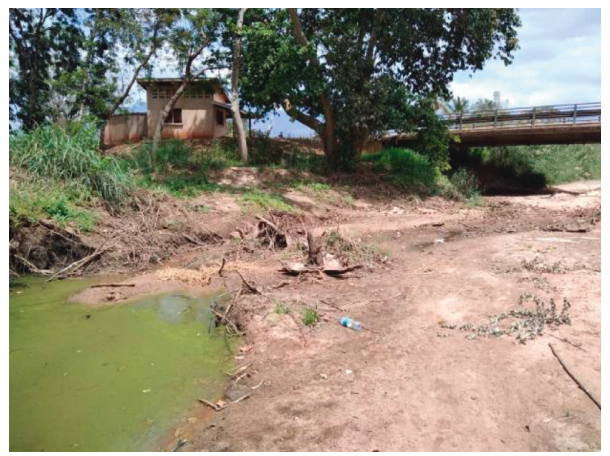

(c)

Figure 11: (a) Photos taken (downstream Mindu Dam) on morning hours just after the rainfall on the 11th of January 2018. No one (anecdotal observation) could have crossed the bridge (Julius Nyerere Freedom Bridge) to/from Solomon Mahlangu College of Science and Education, Mazimbu, from/to Morogoro Town; (b) for the first time (word of mouth from an aged personnel with 32 years of working experience), the security offices in the campus went flooded and (c) observation at the same point just few months after rainy season (March, April, and May).

\section{Conclusion}

Flash floods of any nature increase the vulnerability of humans, livestock, and aquatic resources. The paper analyzed the flash flood event which was attributed to heavy rainfall (more than $80 \mathrm{~mm} /$ day) on January 11, 2018, in the northern Morogoro, Tanzania. The event caused the overflow of Ngerengere River and some of its tributaries. NOAA GFS and observations (automatic weather) synergistically can be efficient in understanding (for example, local context) the nature of flash flood cases in the study area. The phenomenon was localized (enhanced by the orographic nature of the place) but also steered by the presence of the ITCZ and the tropical cyclone Berguitta (which was the dominant weather over the Indian Ocean). Anthropogenic activities (observed siltation of the Ngerengere River) could have also contributed to the magnitude/severity of the damages. For studying the nature and impacts of flash floods in the region, installation of the automatic weather stations and their integration into the systems of national meteorological centers is inevitable. Additionally, as part of an integrated disaster risk reduction and/or adoption, there is a need for reviewing catchments management policies.

\section{Data Availability}

The data used to support the findings of this study are available from the corresponding author upon request.

\section{Conflicts of Interest}

The authors declare that there are no conflicts of interest.

\section{Acknowledgments}

The authors acknowledge the support from staff at the College of Science and Education, Sokoine University of Agriculture, Morogoro, Tanzania. The authors thank Wami Ruvu Basin Authority and the Morogoro Municipal Council through Morogoro Urban Water Supply Authority (MORUWASA). This work was supported by the University of Venda, Limpopo, South Africa.

\section{References}

[1] The University Corporation for Atmospheric Research, Flash Flood Early Warning System Reference Guide, University Corporation for Atmospheric Research, Boulder, CO, USA, 2010, http://www.meted.ucar.edu/communities/hazwarnsys/ ffewsrg/FF_EWS.pdf.

[2] E. S. Kim and H. I. Choi, "Assessment of vulnerability to extreme flash floods in design storms," International Journal of Environmental Research and Public Health, vol. 8, no. 7, pp. 2907-2922, 2011.

[3] E. S. Reichwaldt and A. Ghadouani, "Effects of rainfall patterns on toxic cyanobacterial blooms in a changing climate: between simplistic scenarios and complex dynamics," Water Research, vol. 46, no. 5, pp. 1372-1393, 2012. 
[4] S. Rozalis, E. Morin, Y. Yair, and C. Price, "Flash flood prediction using an uncalibrated hydrological model and radar rainfall data in a Mediterranean watershed under changing hydrological conditions," Journal of Hydrology, vol. 394, no. 1-2, pp. 245-255, 2010.

[5] M. Acosta-Coll, F. Ballester-Merelo, M. Martinez-Peiró et al., "Real-time early warning system design for pluvial flash floods-A review," Sensors, vol. 18, no. 7, p. 2255, 2018.

[6] J. Zogg and K. Deitsch, The Flash Flood Potential Index at WFO Des Moines, Iowa, National Weather Service, Des Moines, LA, USA, 2013, http://www.crh.noaa.gov/Image/ dmx/hydro/FFPI/FFPI_WriteUp.pdf.

[7] B. E. Montz and E. Gruntfest, "Flash flood mitigation: recommendations for research and applications," Environmental Hazards, vol. 4, no. 1, pp. 15-22, 2002.

[8] L. Marchi, M. Borga, E. Preciso, and E. Gaume, "Characterisation of selected extreme flash floods in Europe and implications for flood risk management," Journal of Hydrology, vol. 394, no. 1-2, pp. 118-133, 2010.

[9] Z. W. Kundzewicz and P. Matczak, "Extreme hydrological events and security," Proceedings of the International Association of Hydrological Sciences, vol. 369, pp. 181-187, 2015.

[10] J. M. Huho and R. C. Kosonei, "Understanding extreme climatic events for economic development in Kenya," IOSR Journal Of Environmental Science Toxicology And Food Technology Ver. I, vol. 8, no. 2, pp. 14-24, 2014, http://www. iosrjournals.org.

[11] World Wide Fund For Nature, Climate Change Impacts on East Africa: A Review of the Scientific Literature. East Africa Climate Impacts, World Wide Fund For Nature, Gland, Switzerland, 2006.

[12] K. B. Mafuru and T. Guirong, "Assessing prone areas to heavy rainfall and the impaction of the upper warm temperature anomaly during March-May rainfall season in Tanzania," Advances in Meteorology, vol. 2018, Article ID 8353296, 17 pages, 2018.

[13] T. Ja and K. M, "Review of spatial and temporal distribution of landslides in Tanzania," Journal of Ecosystem \& Ecography, vol. 7, no. 3, 2017.

[14] The United Republic of Tanzania, National Adaptation Programme of Action, Global Environment Facility (GEF), Washington, DC, USA, 2007, https://unfccc.int/resource/ docs/napa/tza01.pdf.

[15] S. Boamah, F. Armah, V. Kuuire, I. Ajibade, I. Luginaah, and G. McBean, "Does previous experience of floods stimulate the adoption of coping strategies? Evidence from cross sectional surveys in Nigeria and Tanzania," Environments, vol. 2, no. 4, pp. 565-585, 2015.

[16] M. Mollet and D. Barelli, Rapid Agriculture Needs Assessment in Response to the El-Niño Effects in the United Republic of Tanzania, Food and Agriculture Organization of the United Nations, Rome, Italy, 2016, http://www.fao.org/fileadmin/ user_upload/emergencies/docs/TZ_final_needs_assessment_ report-reformatted-new.pdf.

[17] A. L. Kijazi and C. J. C. Reason, "Analysis of the 2006 floods over Northern Tanzania," International Journal of Climatology, vol. 29, no. 7, pp. 955-970, 2009.

[18] S. Pavagadhi and R. Balasubramanian, "Toxicological evaluation of microcystins in aquatic fish species: current knowledge and future directions," Aquatic Toxicology, vol. 142-143, pp. 1-16, 2013.

[19] M. Natkhin, O. Dietrich, M. P. Schäfer, and G. Lischeid, "The effects of climate and changing land use on the discharge regime of a small catchment in Tanzania," Regional Environmental Change, vol. 15, no. 7, pp. 1269-1280, 2015.

[20] M. P. Schaefer and O. Dietrich, Impact of Land Use Change and Water Abstractions on the Discharge of the Ngerengere River in Tanzania and its Implications for Agriculture and Food Security, Institute of Landscape Hydrology, Muncheberg, Germany, 2016.

[21] The United Republic of Tanzania, The United Republic of Tanzania. National Adaptation Programme of Action (NAPA), International Institute for Environment and Development, London, UK, 2007.

[22] S. L. M. Traerup, R. A. Ortiz, and A. Markandya, "The costs of climate change: a study of cholera in Tanzania," International Journal of Environmental Research and Public Health, vol. 8, pp. 4386-4405, 2030.

[23] M. C. Gomani, O. Dietrich, G. Lischeid et al., "Establishment of a hydrological monitoring network in a tropical African catchment: an integrated participatory approach," Physics and Chemistry of the Earth, Parts $A / B / C$, vol. 35, no. 13-14, pp. 648-656, 2010.

[24] The United Republic of Tanzania, Population Distribution by Age and Sex, National Bureau of Statistics, Dar Es Salaam, Tanzania, 2013, https://ihi.eprints.org/2169/1/Age_Sex_Distribution.pdf.

[25] GLOWSFIU, Climate, Forest Cover, and Water Resources Vulnerability Wami/Ruvu Basin, Tanzania, Florida International University, North Miami, FL, USA, 2014.

[26] M. Gomani, F. Mahay, B. Mbilinyi, O. Dietrich, and G. Lischeid, "Establishment of a hydrological monitoring system through a participatory approach in a small tropical catchment in Tanzania: learning hydrology from the local people," vol. 2069, pp. 8-11, 2009, http://www.tropentag.de/ 2009/abstracts/links/Dietrich_yGx508hY.pdf.

[27] S. Ernest, A. R. Nduganda, and J. J. Kashaigili, "Urban climate analysis with remote sensing and climate observations: a case of Morogoro municipality in Tanzania," Advances in Remote Sensing, vol. 6, no. 2, pp. 120-131, 2017.

[28] M. Borga, E. N. Anagnostou, G. Blöschl, and J.-D. Creutin, "Flash floods: observations and analysis of hydrometeorological controls," Journal of Hydrology, vol. 394, no. 1-2, pp. 1-3, 2010.

[29] M. L. Apsley, K. J. Mulder, and D. M. Schultz, Reexamining the United Kingdom's Greatest Tornado Outbreak: Forecasting the Limited Extent of Tornadoes along a Cold Front, University of Manchester, Manchester, UK, 2016.

[30] F. Tuluri, R. S. Reddy, Y. Anjaneyulu, J. Colonias, and P. Tchounwou, "Environmental modeling, technology, and communication for land falling tropical cyclone/hurricane prediction," International Journal of Environmental Research and Public Health, vol. 7, no. 5, pp. 1937-1952, 2010.

[31] M. New, B. Hewitson, D. B. Stephenson et al., "Evidence of trends in daily climate extremes over Southern and West Africa," Journal of Geophysical Research Atmospheres, vol. 111, no. 14, 2006.

[32] W. C. Ndomeni, E. Cattani, A. Merino, and V. Levizzani, “An observational study of the variability of East African rainfall with respect to sea surface temperature and soil moisture," Quarterly Journal of the Royal Meteorological Society, vol. 144, pp. 384-404, 2018.

[33] J. Paavola, "Livelihoods, vulnerability and adaptation to climate change in Morogoro, Tanzania," Environmental Science \& Policy, vol. 11, no. 7, pp. 642-654, 2008.

[34] O. N. Kimambo, J. R. Gumbo, and H. Chikoore, "The occurrence of cyanobacteria blooms in freshwater ecosystems and their link with hydro-meteorological and environmental 
variations in Tanzania," Heliyon, vol. 5, no. 3, article e01312, 2019.

[35] T. H. Dewan, "Societal impacts and vulnerability to floods in Bangladesh and Nepal," Weather and Climate Extremes, vol. 7, pp. 36-42, 2015.

[36] D. Anderson, "HABs in a changing world: a perspective on harmful algal blooms, their impacts, and research and management in a dynamic era of climactic and environmental change," in Proceedings of the 15th International Conference on Harmful Algae, vol. 3-17, Changwon, Korea, October 2014.

[37] J. Heisler, P. M. Glibert, J. M. Burkholder et al., "Eutrophication and harmful algal blooms: A scientific consensus," Harmful Algae, vol. 8, no. 1, pp. 3-13.

[38] J. Ringo, "Influence of governance and institutional structures on flood management and control in Kilosa district, Tanzania," International Journal of Scientific and Research Publications (IJSRP), vol. 8, no. 4, 2018.

[39] A. Gastinger, A. Neoh, A. Cardwell et al., Building Just Responses to Flooding, Centre for Community Initiatives (CCI), Dar es Salaam, Tanzania, 2017.

[40] R. L. Wilby and R. Keenan, "Adapting to flood risk under climate change," Progress in Physical Geography: Earth and Environment, vol. 36, no. 3, pp. 348-378, 2012. 

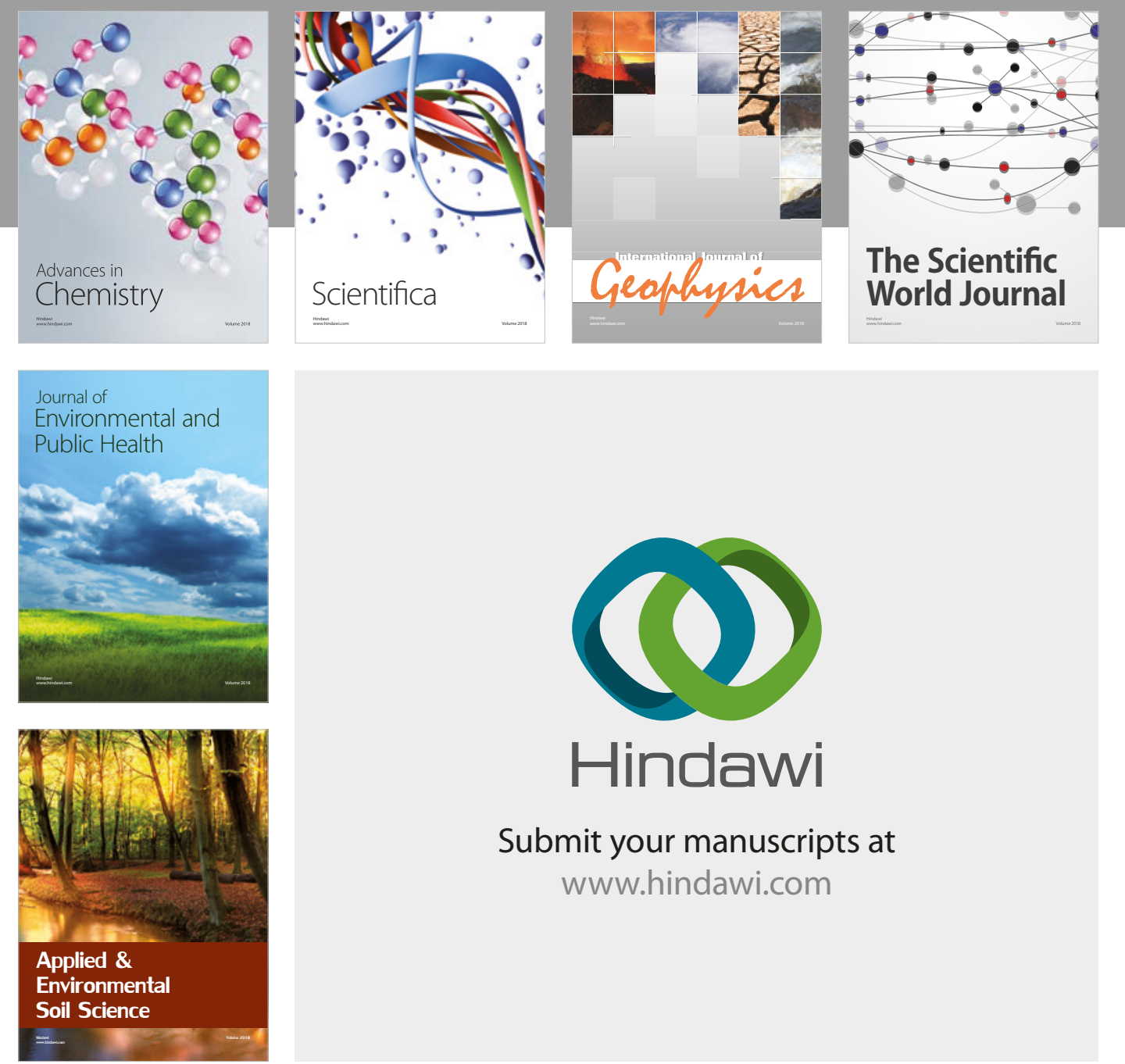

The Scientific

\section{World Journal}
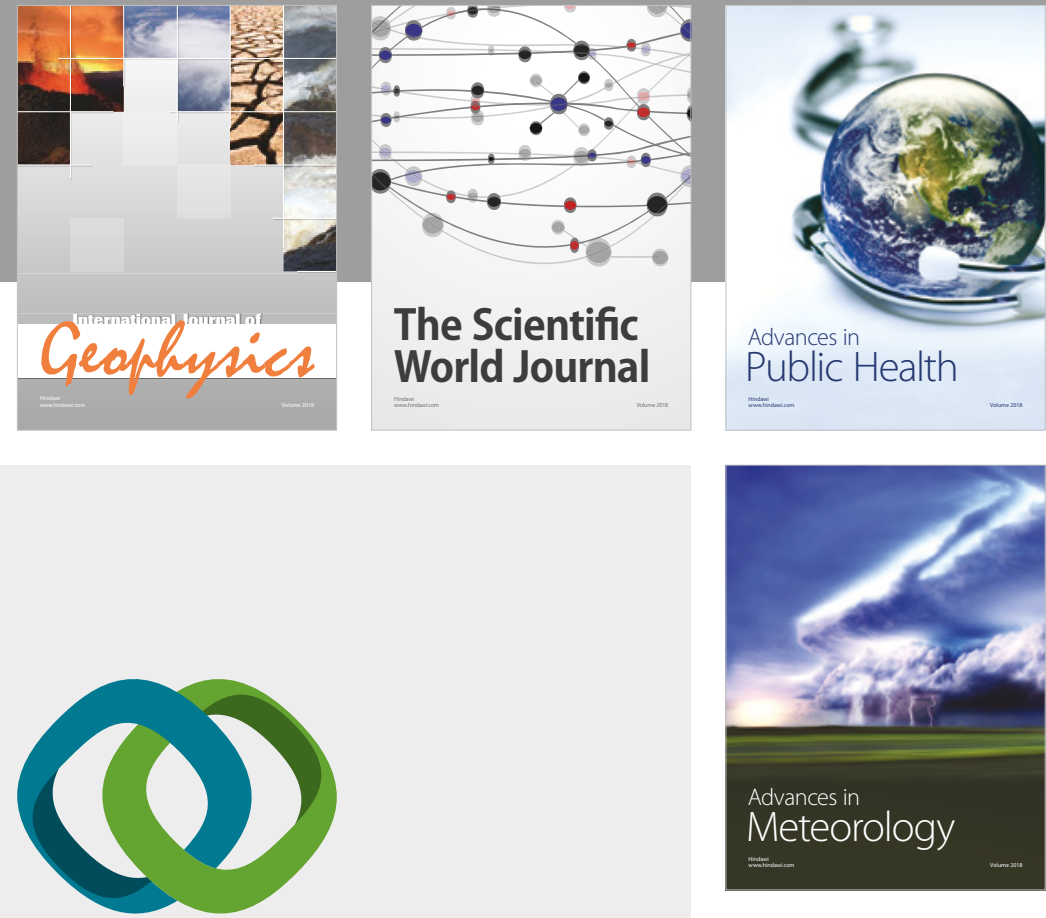

Advan

Public Health

\section{Hindawi}

Submit your manuscripts at

www.hindawi.com
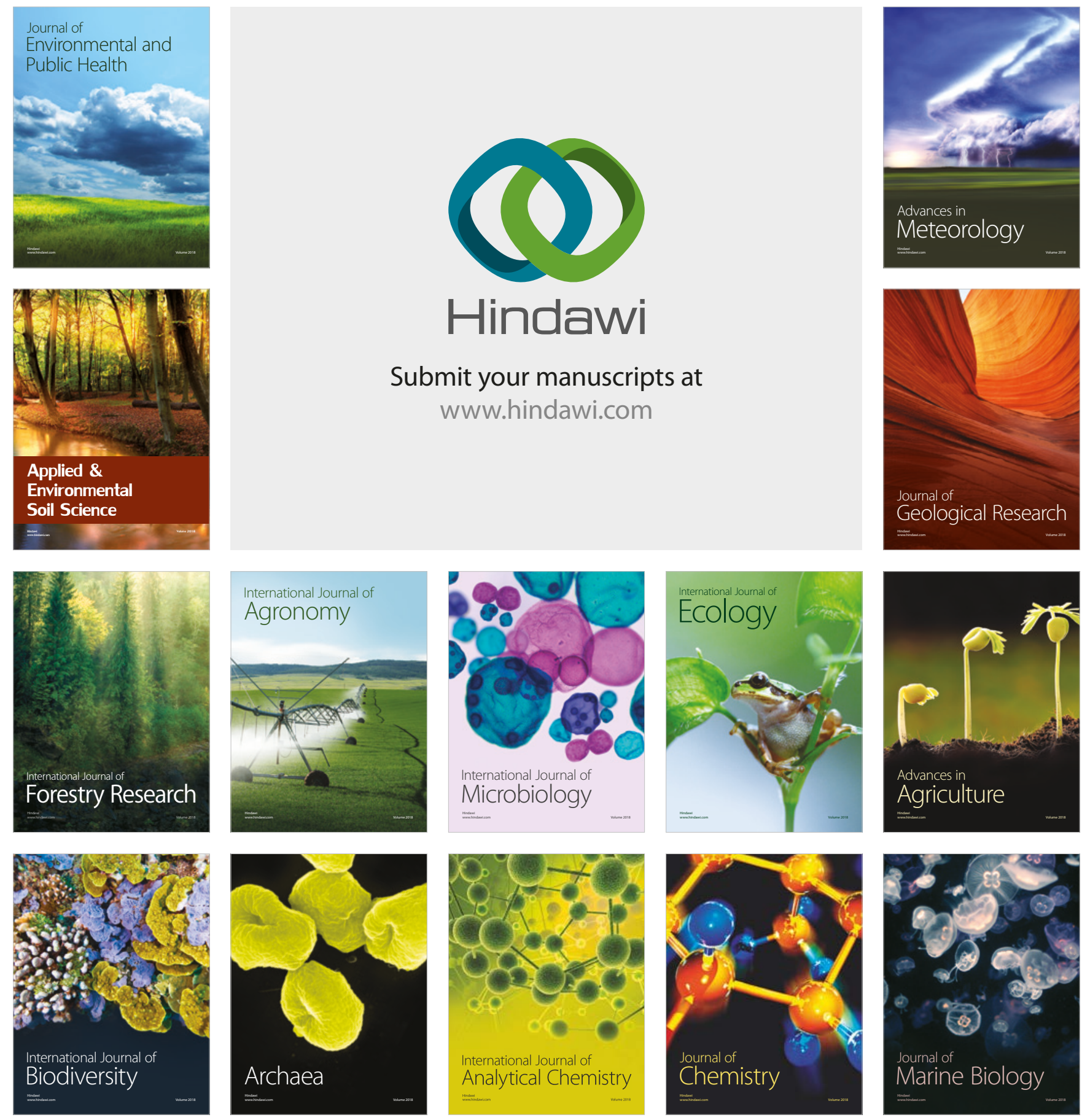